\title{
UČEBNÉ ZDROJE UČITELOV TECHNIKY NA ZÁKLADNÝCH ŠKOLÁCH V SR
}

\author{
LUKÁČOVÁ Danka - BÁNESZ Gabriel - VRAŇÁKOVÁ Zuzana, SR
}

\begin{abstract}
Resumé
Základným pilierom učitel’ov základných škôl vo výučbe sú obsahové a výkonové štandardy predmetov a učebné zdroje jednotlivých vyučovacích predmetov. Dostupnost' učebníc na Slovensku v ostatných rokoch zaostáva, učitelia avizujú ich nedostatok pre žiakov. Predmet technika prešiel od roku 2015 zásadnými obsahovými zmenami, ktoré vyžadujú ich reflexiu v nových učebniciach i pracovných zošitoch. Ciel'om tohto príspevku je vyhodnotit' dostupnost' učebných zdrojov pre predmet technika so zameraním na elektronické učebné zdroje. Na výskum bol použitý dotazník vlastnej konštrukcie, ktorý bol zaslaný na 110 základných škôl s návratnost’ou 46 \%. Výsledky dotazníka boli spracované metódami popisnej štatistiky. Bolo zistené, že printové učebnice ako zdroj odborných informácií sú na pokraji záujmu a učitelia viac uprednostňujú elektronické učebné zdroje.
\end{abstract}

Kl’účové slová: učebnice, elektronické zdroje, učitelia, dotazník

\section{TEACHING RESOURCES OF TECHNICAL TEACHERS AT PRIMARY SCHOOLS IN THE SLOVAK REPUBLIC}

\begin{abstract}
The basic pillars of primary school teachers in teaching are the content and performance standards of subjects and teaching resources of individual subjects. The availability of textbooks in Slovakia has lagged behind in recent years, and teachers are announcing their lack for pupils. The subject of technology has undergone fundamental content changes since 2015, which require their reflection in new textbooks and workbooks. The aim of this paper is to evaluate the availability of learning resources for the subject of technology with a focus on electronic learning resources. A questionnaire of our own design was used for the research, which was sent to 110 primary schools with a return of $46 \%$. The results of the questionnaire were processed by methods of descriptive statistics. It has been found that print textbooks are on the verge of interest as a source of professional information, and teachers prefer electronic learning resources.
\end{abstract}

Key words: textbooks, electronic resources, teachers, questionnaire

\section{Úvod}

Akademický rok 20/21 sa všetkým učitel'om a žiakom zafixuje ako rok, v ktorom prezenčnú výučbu nahradila dištančná výučba. $\mathrm{V}$ jej začiatkoch sa borili školy najmä s technickými problémami a zaobstarávali pre učitel'ov počítače, kamery, mikrofóny... Takisto žiaci a ich rodiny sa snažili technicky zabezpečit' dištančnú výučbu žiakov. S odstupom času sa problémy dištančnej výučby presunuli do sféry obsahu jednotlivých predmetov - ako čo najkvalitnejšie žiakom prezentovat' učivo. Základným pilierom učitel'ov základných škôl vo výučbe sú obsahové a výkonové štandardy predmetov a učebné zdroje jednotlivých vyučovacích predmetov. Dostupnost' učebníc na Slovensku v ostatných rokoch zaostáva, učitelia avizujú ich nedostatok pre žiakov. To potvrdzuje aj výskum, ktorý bol ukončený v roku 2015 s ciel'om overit' skutočnú realitu na základných školách po zavedení kurikulárnej reformy v technickom vzdelávaní. Zo záverov výskumu vyplynulo, že učitelia pocit’ujú 
obrovský nedostatok kvalitných učebníc a ako zdroj učebných materiálov a úloh použivajú len internet (Hašková, 2015).

Učitelia sa v mnohých prípadoch nemôžu opierat' o klasické printové zdroje, najmä v predmete technika. Začali vyhl'adávat' elektronické učebné zdroje, ktoré by mohli so žiakmi zdiel'at'. Je to najmä z toho dôvodu, že predmet technika prešiel v ostatných rokoch zásadnými obsahovými zmenami, ktoré sa neodrážajú v obsahu učebníc a pracovných zošitov. V našom prieskume sme preto chceli zistit', či majú učitelia tohoto predmetu dostatok učebných zdrojov.

Učebnicu viacerí autori definujú ako knihu, ktorá bola vytvorená pre vyučovací proces (Laws, Horsley, 1992). Učebnicou môžeme rozumiet' aj iné učebné texty, ktoré sú v súlade s kurikulárnymi dokumentmi, pričom expozícia učiva je didakticky premyslená (Vaněček, 1995). Z vyššie uvedených definícií je zrejmé, že záleží na tom, z akého uhla pohl'adu a v akom systéme budeme na učebnicu nahliadat'. K tomuto poznamenáva Průcha (1998, s. 13): "Učebnica je začlenená najmenej do troch systémov - ako edukačný konštrukt, tj. výtvor skonštruovaný pre špecifické účely edukácie, ako súčast' súboru didaktických prostriedkov a ako druh školských didaktických textov" (Průcha, 1998, s. 13-16).

Žijeme v 21. storočí, ktoré so sebou prinieslo (a prináša) prevratné zmeny, predovšetkým v oblasti techniky a informačných technológií. Počítače, notebooky, či dokonca tablety používané vo výučbe boli ešte pred dvadsiatimi, tridsiatimi rokmi nemyslitel'né, alebo boli výsadou niekol'kých málo jedincov. Doba elektronizácie výučbových prostriedkov je $\mathrm{v}$ súčasnosti realitou a mnohé nakladatel'stvá už ponúkajú ku klasickej tlačenej učebnici aj jej elektronickú verziu. V rámci nášho prieskumu sme sa preto orientovali aj na zist'ovanie elektronických učebných zdrojov, ktoré učitelia predmetu technika používajú vo svojej učitel'skej praxi.

\section{Ciele a metódy prieskumu}

Ciel'om tohto príspevku je vyhodnotit' dostupnost' učebných zdrojov pre predmet technika so zameraním na elektronické učebné zdroje. Hlavný ciel' sme členili na tri čiastkové ciele:

Ciel' 1: Zistit', ktoré zdroje odborných informácií učitelia vo výchovno-vzdelávacom procese uprednostňujú.

Ciel' 2: Zistit', ktoré zdroje informácií učitelia využívajú pri získavaní nových odborných informácií najčastejšie.

Ciel' 3: Zistit', v akej miere sú zdrojom nových odborných informácií učitel'ov masmediálne informačné prostriedky.

Pre realizáciu prieskumu sme zvolili kvalitatívnu metódu s využitím dotazníka. Pre vytvorenie dotazníka sme použili elektronickú platformu Google doc. Vytvorili sme neštandardizovaný dotazník, ktorý obsahoval 17 položiek rôznych typov (uzavreté, otvorené, škálované). Pri vyhodnocovaní získaných odpovedí sme použili metódy popisnej štatistiky. Použili sme kvantitatívne metódy spracovania získaných výsledkov prieskumu formou štatistickej deskripcie. Kvalitatívne metódy sme použili pri analýze konkrétnych odpovedí respondentov, najmä v rámci škálovaných položiek a otvorených položiek.

Prieskum bol realizovaný v priebehu mesiaca február 2021. Dotazník sme elektronickou poštou rozposlali riaditel'om 110 základných škôl, pričom bol určený učitel'om, ktorí v tomto školskom roku vyučujú predmet technika na druhom stupni ZŠ. V priebehu troch týždňov odpovedalo na dotazník 50 respondentov, ktorí tvorili prieskumný súbor. Návratnost' dotazníkov bola $45 \%$.

Do prieskumu sa zapojilo 50 respondentov, z toho bolo 32 žien a 18 mužov. Z prieskumu vyplynulo, že až $52 \%$ učitel'ov, ktorí sa zapojili do nášho prieskumu nemá kvalifikáciu, to znamená z 50 respondentov nemá kvalifikáciu pre predmet technika 26 učitel'ov. Najviac respondentov (36\%, teda 18 učitel'ov) učí predmet technika viac ako desat' rokov, 12 \% respondentov (6 učitel'ov) učí predmet 
technika od 5 do 10 rokov, a zhodne po $26 \%$ respondentov sa vyjadrilo, že vyučuje techniku menej ako dva roky alebo od dvoch do pät' rokov.

Z priestorových dôvodov v tomto príspevku neuvádzame vyhodnotenie všetkých položiek dotazníka, ale iba tých, ktoré sa vzt'ahujú k vytýčeným ciel'om.

\section{Výsledky prieskumu}

Prvé štyri položky dotazníka boli zamerané na zistenie základných údajov o respondentoch: pohlavie, kvalifikácia, prax, výučba predmetu technika. Piatou položkou dotazníka (Graf 1) sme zist'ovali, ako často používajú učitelia na hodinách ako zdroje odborných informácií tlačené alebo elektronické učebnice, pracovné zošity, prezentácie a náučné videá. $\mathrm{V}$ odpovedi mohli respondenti využit' škálovanie, čiže pre každý z učebných zdrojov mohli vybrat' frekvenciu používania: pravidelne, často, zriedkavo, nikdy. Z odpovedí vyplýva, že všetci učitelia používajú tlačenú učebnicu, no s rôznou frekvenciou. Pravidelne používa učebnicu na hodinách 11 učitel'ov, pričom miera využívania učebnice nezávisí od kvalifikovanosti učitel'a. Často používa učebnicu 16 učitel'ov, pričom až o 50 \% viac kvalifikovaných učitel'ov siaha po učebnici častejšie ako nekvalifikovaní učitelia. Zriedkavo používa učebnicu 23 učitel'ov, z čoho dvojnásobok tvoria nekvalifikovaní učitelia. To znamená, že $52 \%$ učitel'ov používa učebnicu ako zdroj odborných informácií pravidelne alebo často, pričom v odpovediach prevažujú kvalifikovaní učitelia. 48 \% učitel'ov používa učebnicu zriedkavo, pričom väčšinu z nich tvoria učitelia bez kvalifikácie.

\section{Graf 1 - Zdroje odborných informácií používaných vo výchovno-vzdelávacom procese}

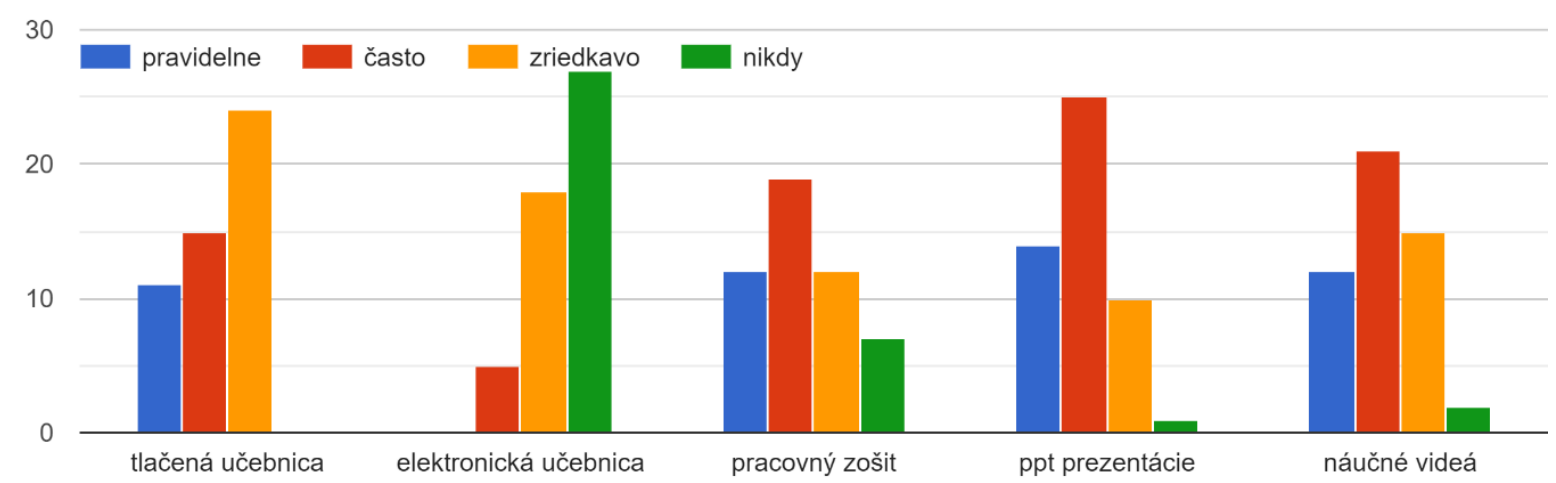

Pri položkách orientovaných na používanie prezentácií boli odpovede respondentov úplne jednoznačné. Až 80 \% respondentov uviedlo, že používajú prezentácie ako zdroje odborných informácií na vyučovacích hodinách pravidelne alebo často. Odpovede boli takmer identické u kvalifikovaných aj nekvalifikovaných učitel'ov.

Značné rozdiely sme zistili v odpovediach respondentov v otázke používania multimédií, konkrétne náučných videí ako zdrojov odborných informácií na vyučovacích hodinách. Najviac respondentov uviedlo, že náučné videá používajú často (20 respondentov), pričom v odpovediach jednoznačne prevažujú kvalifikovaní učitelia. Pravidelne používa náučné videá na hodine 12 učitel'ov.

Položka 13 (Graf 2) bola kl'účovou položkou pri zist'ovaní zdrojov, z ktorých učitelia získavajú nové odborné poznatky. Učitel'om sme dali možnost' výberu zo štyroch druhov informačných zdrojov odborná literatúra, odborný časopis, internet, televízia, pričom pri každej možnosti mali určit’ 
frekvenciu používania tohto zdroja. Odpovede respondentov sme vyhodnocovali opät' s súvislosti s kvalifikáciou respondentov. Po odbornej literatúre siahne pravidelne alebo často 23 respondentov, z toho 13 kvalifikovaných a 10 nekvalifikovaných, čo nie je adekvátne meratel'ný rozdiel. Škálu zriedkavo alebo nikdy uviedlo 27 respondentov, z toho 11 kvalifikovaných a 16 nekvalifikovaných, $\mathrm{z}$ čoho môžeme dedukovat', že v rámci používania odbornej literatúry nie sú rozdiely v ich využívaní učitel'mi v rámci kvalifikácie. Celkovo môžeme konštatovat', že odborná literatúra nepatrí medzi vyhl'adávané zdroje odborných informácií. Vel'mi obdobné údaje sme získali vyhodnotením položky zameranej na zist'ovanie využívania odborných časopisov. Pravidelne alebo často siahne po odborných časopisoch len 18 respondentov, $\mathrm{z}$ toho 10 kvalifikovaných učitel'ov a 8 nekvalifikovaných. Až 32 respondentov ich používa zriedkavo alebo nikdy, čo uviedlo aj 14 kvalifikovaných učitel'ov. Vyrovnanejšie odpovede sme zaznamenali vo vzt'ahu k televíznym reláciám, ktoré považuje za svoj zdroj nových odborných informácií 50 \% respondentov. Druhá polovica respondentov uviedla, že tento zdroj informácií využíva zriedkavo alebo nikdy (11 kvalifikovaných a 14 nekvalifikovaných učitel'ov). Súhrnne môžeme konštatovat', že odborné časopisy a televízne relácie ako masmediálne zdroje odborných informácií patria medzi priemerne vyhl'adávané u učitel'ov techniky.

Medzi najčastejšie vyhl'adávané zdroje nových odborných informácií podl'a vyjadrení respondentov patrí internet, ktorý uviedlo 49 respondentov ako svoj pravidelne alebo často navštevovaný zdroj informácií, čo je takmer $100 \%$ respondentov.

\section{Graf 2 Masmediálne zdroje získavania nových odborných informácií}

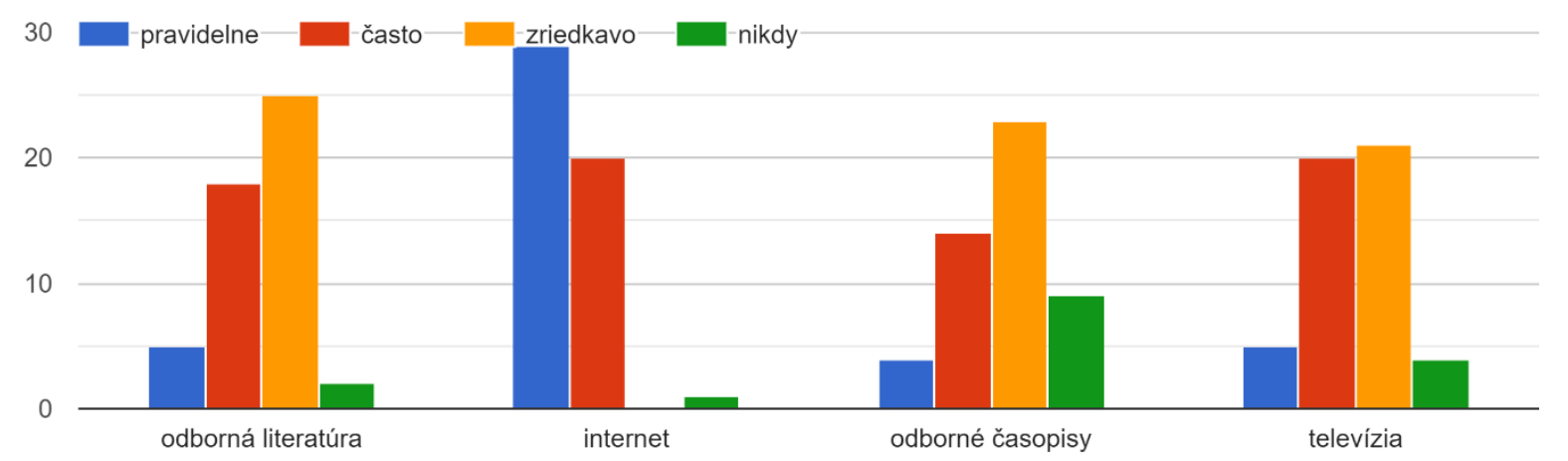

Oblasti zdrojov nových odborných informácií sme špecifikovali v položkách 14, 15 a 16, v ktorých sme skúmali konkrétne zdroje informácií, ktoré učitelia preferujú v rámci internetových stránok, odborných časopisov a televíznych relácií. $\mathrm{Z}$ odpovedí respondentov vyplynulo, že $\mathrm{k}$ najčastejšie navštevovaným internetovým stránkam patria youtube (88 \% respondentov), zborovňa ( $84 \%)$, wikipédia (50 \%), datakabinet (28 \%), oškole (20 \%) najmä z dôvodu, že ide o stránky všeobecne známe učitel'skej verejnosti. Zo stránok, ktoré sú tematicky zamerané na oblasti blízke technike respondenti poznali a uvádzali pinterest (54 \%), veda-technika (38 \%), eductech (20\%). Menej ako desat' percent učitel'ov poznalo stránky: technika hravo, týždeňvedy, amavet a vedanadosah. V možnosti „iné“ uviedol jeden respondent stránku mozaweb.

V rámci odborných a populárno-náučných časopisov a televíznych relácií sme učitel’om ponúkli najznámejšie tituly a škálovaním sme chceli zistit' frekvenciu ich sledovania. Z odpovedí respondentov vyplynulo, že odborný časopis Technika a vzdelávanie pozná a pravidelne alebo často 
ho používa len 9 respondentov, čo je 18 \% respondentov. Populárno-náučný časopis Quark, magazín o vede a technike pozná len 5 respondentov. V položke 16 sme umožnili respondentom uviest' iné časopisy, ktoré sledujú častejšie a respondenti uvádzali nasledovné tituly: 100+1, Vesmír, Urob si sám, Jak se to dělá.

V rámci masmediálnych zdrojov sú najviac využívané učitel'mi televízne relácie. 38 \% respondentov sleduje pravidelne alebo často televíznu reláciu Svet technológií, 18 (36 \%) respondentov uviedlo reláciu VAT a $15(30 \%)$ respondentov uviedlo, že pravidelne alebo často sleduje reláciu Veda na dosah. Viac ako 60 \% respondentov však uvedené relácie sleduje zriedkavo alebo nikdy. Respondenti, ktorí využili možnost' napísania inej relácie uvádzali: Postav dom, zasad’ strom, Vychytávky, Prima zoom, Discovery.

\section{Diskusia a záver}

$\mathrm{V}$ rámci vyhodnotenia prieskumu sme analyzovali odpovede respondentov $\mathrm{v}$ súvislosti so stanovenými čiastkovými ciel'mi.

Ciel' 1: Zistit', ktoré zdroje odborných informácií učitelia vo výchovno-vzdelávacom procese uprednostňujú.

Nadpolovičná väčšina tých učitel'ov, ktorí sa zapojili do nášho prieskumu, uprednostňuje ako zdroj odborných informácií vo výchovno-vzdelávacom procese prezentácie, multimediálne náučné videá a pracovné zošity. Túto skutočnost' môžeme chápat' ako prirodzený dôsledok elektronizácie školstva v priebehu predchádzajúcich rokov, ked' takmer všetci pedagógovia absolvovali vzdelávanie v oblasti používania IKT vo výchovno-vzdelávacom procese, ale aj ako dôsledok momentálneho dištančného vzdelávania zapríčineného pandemickou situáciou Covid 19.

Ciel' 2: Zistit', ktoré zdroje informácií učitelia využívajú pri získavaní nových odborných informácií a poznatkov najčastejšie.

K najčastejšie používaným zdrojom nových odborných informácií patrí internet, ktorý uviedlo $98 \%$ učitel'ov zapojených do prieskumu. Toto zistenie je absolútne očakávané a prirodzené vzhl'adom na súčasné trendy elektronizácie. 50 \% respondentov uviedlo aj televízne relácie.

Ciel' 3: Zistit', v akej miere sú zdrojom nových odborných informácií masmediálne informačné prostriedky.

Masmediálne informačné prostriedky, konkrétne odborná literatúra, časopisy a televízne relácie sú zdrojom nových informácií vo vel'mi malej miere. Televízne relácie venované vede a technike sleduje $50 \%$ respondentov, konkrétne relácie Svet technológií a VAT. Odborné časopisy uvádzalo približne 36 \% respondentov, ktorí uvádzali najmä populárno-náučné časopisy pre domácich majstrov. Je prekvapivé, že časopis Technika a vzdelávanie, ktorý je zvlášt' zameraný na odborno-didaktické témy v rámci predmetu technika, pozná len 18 \% respondentov.

Tabul'ka 1 - Frekvencia použivania učebných zdrojov učitel'mi techniky

\begin{tabular}{|l|c|c|}
\hline \multicolumn{1}{|c|}{ druh zdroja/frekvencia používania } & pravidelne/často (\%) & zriedkavo/nikdy \\
\hline tlačené učebnice & $52 \%$ & $48 \%$ \\
\hline elektronické učebnice & $10 \%$ & $90 \%$ \\
\hline pracovné zošity & $62 \%$ & $38 \%$ \\
\hline elektronické prezentácie & $80 \%$ & $20 \%$ \\
\hline multimediálne videá & $64 \%$ & $36 \%$ \\
\hline odborná literatúra & $46 \%$ & $54 \%$ \\
\hline odborné časopisy & $36 \%$ & $64 \%$ \\
\hline televízne programy & $50 \%$ & $48 \%$ \\
\hline internet & $98 \%$ & $2 \%$ \\
\hline
\end{tabular}


Pokial' porovnáme zistenia nášho prieskumu s výskumom Haškovej (2015), dochádzame k záveru, že učebnice ako zdroj odborných informácí́ nad'alej zostávajú na pokraji záujmu a učitelia viac vyhl'adávajú informácie na internete. Tu však musíme brat' do úvahy, že oproti roku 2015 je spektrum učebníc, ktoré sú ponúkané učitel’om na trhu ovel'a väčšie a tematicky sú pokryté všetky oblasti vzdelávacích štandardov v predmete technika, či už v printovej alebo elektronickej forme. A preto je potrebné si položit' otázku, či sú učitelia v praxi dostatočne informovaní o nových učebných textoch, ktoré sú dostupné na trhu. Ďalej by sme sa mohli pýtat', v koho kompetencii je zabezpečit' školám všetky potrebné aktuálne učebnice a metodiky, ktoré sú určené pre pedagógov.

V roku 2017 uskutočnili prieskum medzi učitel'mi techniky na ZŠ v okrese Prievidza M. Ďuriš a I. Pandurovič (2017), ktorého výsledky zverejnili v rozsiahlej štúdii v časopise Technika a vzdelávanie. Prieskum uskutočnili formou neštandardizovaného dotazníka, na ktorý odpovedalo 49 učitel'ov techniky na ZŠ. Z odpovedí vyplynulo, že najpreferovanejším informačným zdrojom pre 86 \% učitel'ov je učebnica Technická výchova pre 5. až 9. ročník základných škôl, čo sa zhoduje s našimi zisteniami s tým rozdielom, že percento učitel'ov, ktorí preferujú učebnicu Technická výchova pre 5. - 9. ročník je výrazne menšie (50 \%). Kým v roku 2017 bol d’alším preferovaným informačným zdrojom pre 39 učitel'ov ( 80 \%) internet, percento učitel'ov, ktorí preferujú internet ako zdroj odborných informácii výrazne stúplo (95\%). Rozdiel nastal aj v preferenciách pracovných zošitov. Kým v roku 201726 učitel'ov (53 \%) používalo pracovné zošity od vydavatel'stva Dr. Josef Raabe Slovensko, podl'a nášho prieskumu v súčasnosti učitelia preferujú pracovné zošity Hravá technika od vydavatel'stva Taktik. Táto zmena je pravdepodobne spôsobená vydaním nových pracovných zošitov a učebníc vydavatel'stvom Taktik, ktoré reflektujú inovované vzdelávacie štandardy predmetu technika. V rámci masmediálnych zdrojov boli výsledky prieskumov porovnatel'né, až vel'mi podobné.

Z výsledkov výskumov je zrejmé, že učitelia okrem internetu potrebujú pre kvalitnú výučbu aj klasické učebnice a pracovné zošity. Pre predmet technika nie je dostatok učebníc na základných školách, dokonca pre niektoré ročníky do roku 2021 učebnice neboli vydané. Situáciu by mali riešit' zodpovedné štátne inštitúcie, ale aj samotné základné školy a učitelia môžu byt' iniciátormi nákupu nových učebných materiálov, ktoré môžu pomôct' skvalitnit' výučbu žiakov a zatraktívnit' predmet technika.

Článok vznikol ako súčast’ riešenia výskumnej úlohy KEGA 012UKF-4/2020 Elektronické vzdelávacie moduly pre meranie faktorov pracovného prostredia.

\section{Literatúra}

Ďuriš, M. \& Pandurovič, I. (2017). Vybrané klúčové (profesijné ) kompetencie učitel'ov techniky v nižšom strednom vzdelávaní. In Technika a vzdelávanie. 2017, 6 (2). pp. 22-30.

Hašková, A. (2015). Dopad obsahovej reformy na realizáciu technického vzdelávania na ZŠ. In Technika a vzdelávanie. 2017, 4 (2). pp. 8-13.

Laws, K. \& Horsley, M. (1992). Education equity? Textbooks in new South Wales government and non government secondary schools. In Curriculum perspectives. 1992, 12 (3). p. 7-15.

Průcha, J. (1998). Učebnice: Teorie a analýzy edukačního média. Brno: Paido, 1998. 341 p.

Vaněček, E. (1995). Zur Frage der Verständlichkeit und Lernbarkeit von Schulbüchern. In Olechowski, R. (Hrsg.) Schulbuchforschung. Frankfurt am Main: Peter Lang, Europäischer Verlag der Wissenschaften, p. 195-215.

Vraňáková, Z. (2021). Zdroje odborných informácií učitel’ov techniky na ZŠ. Záverečná práca. Nitra: PF UKF, 2021. 


\section{Kontaktná adresa:}

Danka Lukáčová, doc. PaedDr. PhD.,

Katedra techniky a informačných technológií, Pedagogická fakulta UKF, Dražovská 4, 94901 Nitra, SR, tel. +421 376408 342, e-mail: dlukacova@ukf.sk

Gabriel Bánesz, doc. PaedDr. PhD.,

Katedra techniky a informačných technológií, Pedagogická fakulta UKF, Dražovská 4, 94901 Nitra, SR, tel. +421 376408 342, e-mail: gbanesz@ukf.sk

Zuzana Vraňáková, Mgr.,

Katedra techniky a informačných technológií, Pedagogická fakulta UKF, Dražovská 4, 94901 Nitra, SR, e-mail: zuzana.vranakova@student.ukf.sk 